\title{
Egyptian influence on Achaemenid Art
}

\author{
Dr.fawziah Abdullah \\ Associate professor of Ancient Near East, Department of Egyptology, Faculty of \\ Archaeology, Cairo University.
}

The aim of the relevant article is to assemble and to discuss a number of motifs that show Egyptian influences on Achaemenid art. Those motifs include winged disc; winged sphinx; images of the Egyptian deities; rosette s decoration; lady at the window ; and hieroglyphic script on ivories. ${ }^{(i)}$

Cyrus II the Great of the Achaemenid dynasty became the king of Anshan in (559 B.C.), and within twenty years he had conquered all his neighbours. He continued on to put foundation of the Achaemenid Empire, one of the largest empires of ancient world, comprised of Iran, Mesopotamia, Minor Asia ,Syria, Egypt and part of India (ii) Cambyses II (530-522 B.C.), Cyrus's son , conquered Egypt in 525 B.C., but died on his trip home to quell an uprising . His successor Daruis I (522-486)B.C. , perhaps a usurper, suppressed the rebellions and reorganized the empire into provinces called Satrapies, ruled by Persian governors. The political organization reached its zenith under Darius I . The Capital was moved from Pasargadae to Persepolis, with the winter residence at Susa (map no.1). ${ }^{\text {(iii) }}$ While Egypt was the only country that managed to keep its independence for any extended period of time, it was not the only country to revolt against the Persian domination. Other revolts were recorded on Babylonian tablets during the reign of Xerxes. (iv)

Achaemenid art was based on Elamite, and Assyrian motifs and models. This motifs were designed to impress audiences and to impart and reinforce a picture of power and stability. ${ }^{(v)}$ As time progressed, the Achaemenid rule and customs started to influence and spread throughout local cultures. Local coinage and seals showed Achaemenid motifs, and high officials changed their clothing and habits to reflect the Achaemenid practice.

The respect for the local traditions was a Achaemenid characteristic, yet this did not prevent the local people from trying to imitate the imperial styles. The study of Archaemenid art has been hampered by a dearth of freestanding stone and metal sculpture, such as metal vases and figurines, which could be examined in order to isolate important and repeating features. The imperial capitals of Pasargadae and especially Persepolis preserved important samples of the monumental architectural relief. ${ }^{\text {(vi) }}$

While there were two periods of Archaemenid occupation over of Egypt, Archaemenid influence is very minimal. A probable explanation for this is that the essentially decorative character of Archaemenid art had little to contribute to the most extensive Egyptian art. ${ }^{\text {(vii) }}$ The art of the Achaemenid Empire, like its political organization, centered on the king and religion. People in general did not accept this centralization and were not ready to execute it. Like the empire itself, the idea of centralization was a creation of the first Achaemenid kings and shows 
only slight variations under their successors. With very few exceptions, the preserved monuments are royal in origin. Their style is composed of a variety of artistic elements found all over the vast territory of the empire, which reworks had adapted into something new. (viii)

\section{1- Winged disc:}

The origin of the Egyptian winged disc passed via the Syrians and the Hittites to Mesopotamia. At first, it appeared on Mitanian seals about fifteenth century B.C., and was then transmitted to Assyrian and Neo-Babylonian art. Taken over by Achaemenid, it remained an important emblem in Iran until modern times. (ix) The Egyptian winged disc was certainly regarded as a symbol of the sun. It was often attached two coiling uraeus-serpents to its sides or placed two little horns on top of the disc, ${ }^{(\mathbf{x})}$ whereas the Assyrians typically portrayed the disc as a ring containing the upper part of the god in human form as is shown on the left corner of a panel from the ruins of the 'North West Palace' in Nimrud, northern Iraq, dated to 865-860 B.C.(fig.no.1). ${ }^{\text {(xi) }}$

Perhaps the most important symbol used in the Achaemenid reliefs is the winged disc, the symbol is comprised of a large ring adorned with a pair of outstretched wings. It is a religious symbol in general representing deity who that the ancients regarded as the supreme god of the sky. ${ }^{\text {(xii) }}$ the winged disc occurred for the first time on Achaemenid art on the Bisitun rock over the famous inscription of Darius I (carved circa 519 B.C.) (fig.no.2). In addition to the characteristic winged circle, the symbol was depicted as a man wearing a Achaemenid dress and a long, square-cut Assyrian beard. On his hand is the high cylindrical crown, adorned with horns, which was worn by Mesopotamian gods. ${ }^{\text {(xii) }}$

Images of winged disc occurred also in the Achaemenid seals used by the treasury at Persepolis. There was an important cylinder-seal that showed a crowned figure of Daruis I in hunting scene, standing upright on chariot (now in the British museum) (fig.no.3). Other

cylinder-seal have the representations of two archers holding winged disk (fig.no.4) $)^{(\mathbf{x i v})}$. The figure of god, tail and two winged was similar to that winged disk at Bisitun (fig.no.2). ${ }^{\text {(xv) }}$

Comparing this winged disc on Bisitun with any Egyptian winged sun-disc clearly shows significant differences. The Bisitun disc has a winged tail framed by two floating ribbons, and its wings are straight-ended. But the Egyptian symbol has no tail, its wings are much more natural, and instead of ribbons it has two ureai. The main difference between the Achaemenid and Egyptian symbols is the human bust that emerges from the circle, which many scholars use as evidence to propose that the Assyrian symbol of Assur is the prototype of the Bisitun sign (fig.no.2). ${ }^{\text {(xvi) }}$

The fighting of hero with a single animal is represented on some pyramidal stamps seals(dated to fifth century B.C.). On one of those seals, there are images of two upright lions held by a hero. There is the winged sun-disc with Egyptian elements on the top of scene (fig.no.6). (xvii)

The image of hero is represented as victorious over various kinds of animals, such as unicorns, bulls, lions, and horses with gracefully curled wings, all of which represent evil powers. Hunting scenes, and military scenes, on stones, with the winged disk and the bust of Ahura- 
Mazda (fig.no.2). ${ }^{\text {(xviii) }}$ According to many scholars this form of representation symbolizes AhuraMazda in Achaemenid art on a number of reliefs at Persepolis. (xix) Similar shape of a winged sun-disc also occurred in the Achaemenid scenes of the Bisitun rock (fig. no. 2), ${ }^{(\mathbf{x x})}$ and also on the top of relief from the palace of Daruis I at Suse, which represented two sphinx with human head (see fig.no.7).

\section{2-Winged Sphinx:}

The Sphinx is a purely Egyptian creation, first attested in early forth dynasty about 2575 B.C. Around the end of the second millennium B.C., Egyptian female and male Sphinx images were exported to Syria-Palestine , ${ }^{(x x i)}$ where local artist imitated them , mostly in bas-relief and especially as female figures. Sphinx were passed from Syria to Iraq and subsequently to Iran (xxii)

Egyptian Sphinxes were generally associated with the sun-god on one hand and with the king as a "living image" (š̌p cnh)on the other, Horus has sun-disk on his head, most often as ReHorakhty. (xxiii) Sphinx were represented with human face and body of a lion. In the New Kingdom, we find sphinxes with the head of rams and hawks in the front of the temples of Amun at Karnak (fig.no.5) (xxiv)

In the Achaemenid relief from the palace of Daruis I at Suse, two winged sphinx were represented with human head (fig.no.7), winged sun disk on the top of scene. ${ }^{\text {(xxv) }}$ Another sphinx before Daruis I , carved on piece of ivory, with human face, (fig.no.8) and was found in Hasanlu in Iran, dated to the ninth century B.C. ${ }^{(\mathbf{x x v i})}$

\section{3- Egyptian deities :}

Sometimes Egyptian deities are represented in Achaemenid art proving the extensive Egyptian influence on Persian religion and arts, especially gods of fertilization and motherhood,

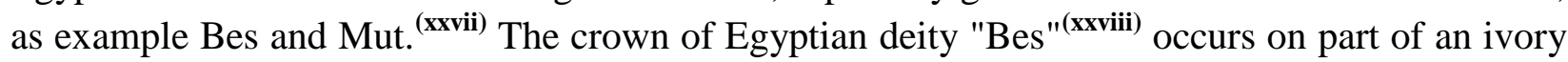
relief found at Susa (now in Louvre museum), dated to fifth century B.C. We notice that the main features of " Bes " in Egyptian art were the same at Susa relief like his famous crown. ${ }^{(x x i x)}$

The Egyptian deity Mut ${ }^{(\mathbf{x x x})}$ is also represented on the ivory relief in the same Egyptian shape, found at Susa (now in Tehran Museum), dated to 6-5 century B.C. (fig.no. 9). ${ }^{\text {(xxxi) }}$

\section{4-Rosette's Decoration :}

The rosette was an Egyptian symbol according to L. Keimer, the origin of this symbol is in Egyptian culture, not Mesopotamian culture as it is commonly thought. ${ }^{\text {(xxii) }}$ It appeared since late Naqqada II on seal impressions, gold and ivory knife-handles an ivory comb, and the Scorpion II mace-head. The surface of the mace-head is shown on a rosette in the upper right corner. It is believed that the rosette was a symbol for kingly authority. The famous Narmer palette also carries the rosette motif. It was created as a memorial to a victorious campaign by that early king. The rosettes above the headdress of queens show their great significance. It continued to have a royal symbolism in later times. It is noted on the left breast of the statue of Meryetamun, daughter of Ramses II (c. 1250 B.C.). This statue is located in the Cairo Museum (xxxiii) 
Achaemenid art transformed the decorative of Egyptian rosette's features. Some pieces of ivory were found in Susa, now at Louvre museum, dated to the fifth century B.C . They were decorated with rosette Such as the frame of comb, (fig.no.10), and piece of incomplete palettes (fig.no.11). ${ }^{\text {(xxiv) }}$ The comb consisted of many pieces (fig.no.10), decorated on two sides with subject of monsters and heroes, the frame decorated with rosette and small triangles, this complex decoration occurred on the New Elamite period on pottery, and around the heads of women.

The rosette also were decorated on incomplete piece ivory palette from Susa now at Louvre museum (fig.no.11). Rosette was decorated inside the two circles, and between two circles another big rosette was decorated. ${ }^{(\mathbf{x x x v})}$

\section{5-The Lady at the window:}

The motive of "Woman at the window" was an aspect of Egyptian goddess Hathor . (xxxvi) The window of Egyptian motif inspired by appearance of the dead over the "nish", or the false door inside the Egyptian tomb, which resembles later with the appearance of the Lady at the window. ${ }^{\text {(xxxvii) }}$

The Syrian and Sumerian also associated this motif with great goddess Inanna, the Babylonian Ishtar, whom they see as, among other things, patron deity of prostitutes and herself a prostitute. ${ }^{\text {(xxxviii) }}$ Her name was Kilili, and was a minor Babylonian goddess. Later, the Greeks associated this motif with Aphrodite. (xxxix)

Tiny ivory carvings of the Lady at the window have been found in the Near East, and they date to the first millennium B.C. There are other many examples from Samaria, Nimrud, Khorasapad, Arslan-Tash, and Susa . ${ }^{(x)}$ The most beautiful of those was The "Mona Lisa" of Nimrud (fig.12). ${ }^{\text {(xli) }}$ Her elegant and ornate coiffure is topped by a hat which might be that of a high priestess. The rich golden ivory carving was probably a furniture appliqué from ancient Nimrud in Babylonia, Mesopotamia, though almost certainly made in Phoenicia, eighth century B.C. (xlii) $^{\text {The }}$

The only example of Woman at the Window at Suse was preserved at the Louvre museum (fig.13), but it was not as beautiful a face as the "Mona Lisa" of Nimrud or the examples of Arslan-Tash. (xliii)

\section{6- Hieroglyphic script signs on Ivories:}

There were many pieces of incomplete ivory palettes found at Susa .They represented various signs of Hieroglyphic script dated back to the fifth century B.C., (now at Louvre museum ). One of these palettes contained cartouche, it seems to be the name of the king Darius. ( fig.no.14) . The Persian scribe was not write the correct signs, but he wrote the sign $\breve{3}$, the name of the king Darius did not contain this sign . ther were also signs "djr", "n" inside a cartouche. (xliv)

The other damage rectangular palette contained the sign "nb" on the right, and the sign "thn" on the left, beside the part of a male human figure (fig.no.15). These signs did not show the correct meaning of hieroglyphic words suggesting that the Persian scribe has imitated these signs without understanding their meanings. ${ }^{(x l v)}$ 


\section{Conclusions}

1- The most important symbol that was used in the Achaemenid reliefs is the Egyptian winged disc which was passed via the Syrians and the Hittites to Mesopotamia, it was then taken over by Achaemenid Persians. It symbolizes Ahura-Mazda in Achaemenid art on a number of reliefs at Persepolis.

2- The Sphinx is a purely Egyptian creation .It were exported to Syria-Palestine, Iraq and then to Iran, where local artist imitated them such what we have in the Achaemenid relief from the palace of Daruis I. Two figures of winged sphinx were represented with human head.

3- Egyptian deities were represented in Persian art proving the great Egyptian influence on the religion , and art of Persians, such as the deity "Bes", and "Mut".

4-Achaemenid art transformed the decorative of Egyptian rosette's features. The Egyptian rosette was decorated on comb and palettes of ivory from Susa.

5- The Egyptian motif "Woman at the Window" represented on miniscule ivory carvings was found in the Near East. They date back to the first millennium B.C. from Samaria, Nimrud , Khorasapad , Arslan-Tash, and Susa. The only Example of "Woman at the Window" was at Susa, preserved at the Louvre museum. It has not as beautiful a face as the "Mona Lisa" of Nimrud or the examples of Arslan-Tash.

6- There were many pieces of incomplete ivory palettes, found at Susa, which represented various signs of Hieroglyphic script, dated to the fifth century B.C. These signs did not show the correct translation of the hieroglyphic text. It is thus believed that the Persian scribe had imitated these symbols without understanding of their meanings.

\section{Endnotes}

${ }^{1}$ B.Teisser, "Ancient Eastern Cylinder Seals from Marcopolic Collection ", USA, 1984,p.45ff ; T.C.Young , "Persians," in : E. M. Meyers(ed.,), The Oxford Encyclopedia of Archaeology, Vol.4, Ancient Near East , New York, (1997), pp.295-300.

2 M.B. Garrison, "Seals and the Elite at Persepolis :Some Observations on Early Achaemenid Persian Art ", Ars Orientalis 2_(1999), p.3.

iii P. Bienkoweski ," Achaemenids," in: P. Bienkoweski \& A .Millard (eds.,), British Museum Dictionary of Ancient Near East, London ,1999, p.1 ff ; V.S. Cuirtis , "Birth of the Persian Empire" , Idea of Iran 1 ,( 2005), pp.88-102.

${ }^{\text {iv }}$ P. Braint , History of Persian Empire ,(550-330)B.C., London ,2002 ,p.16 ff; G .Danial , Birth of Persian Empire , London , 2005 , p.112.

v P. Bienkoweski ," Achaemenids," in: P. Bienkoweski \& A .Millard (eds.,), British Museum Dictionary of Ancient Near East, London ,(1999), p.1 ff, p.1ff; B. Hrouda , Vorderasien I , Mesopotamien, Babylonien, Iran und Anatolian, Handbuch der Archäologie , 1971 , pp.20-23; pl .117 ; G .Contentau , Manuel d'archéologie Orientale ; Depuis les Origines Jusqú à L'epoque Alexandrie IV , Paris ,1931 ,pp. 2135-43 .

${ }^{v i}$ M. Van de Mieroop, A History of the Ancient Near East ,ca 3000-323b.c., $\quad$ USA, 2004, p.279 ; A . Roes , "Achaemenid influence upon Egyptian and Nomad Art ", Atribu Asiae 15, No.1/2 (1952), pp.17-30 ; C.K. Wilkinson, "Assyrian and Persian Art ", $M M A$ 13, No.7 , (1955) , pp.213-15; pp. 222-24; M.B. Garrison , "Seals and the Elite at Persepolis, Some Observations on Early Achaemenid Persian Art ", Ars Orientalis 21 ,(1991),pp.1-2; B. John , Persia and the west : An Archaeological Investigation of the Genesis of Achaemenid Art,London, 2000,p.85 ; pp. 120- 21;pp.134-35; pp.160- 61; figs.5.9,5.10.

vii J. D. Cooney, "Persian Influence in Late Egyptian Art ", JARCE 4 (1965), pp.39-42 .

viii M.C. Root, Art and Archaeology of the Achaemenid Empire, in: J. M .Sasson(ed.,), Civilization of Ancient Near East, New York , 1995 , pp.2615-37. 
ix M.Lurker, The Gods and Symbols of Ancient Egypt , London ,1990 , pp. 185-86.

x W.F. Petrie, Egyptian Decorative Art, London, 1920 ,p. 110 ; fig. 203.

${ }^{x i}$ M.E.L. Mallowan, Nimrud and its Remains, I , London,1966,p. 514; fig.418-419; M. Lurker, The Gods and Symbols of Ancient Egypt,1990, p.130 ;H. Frankfort, Art and Architecture of the Ancient Orient, London , 1958, p.66.

xii T.M. Tytus, "The Egyptian influence on the Persian winged disk, in: Proceeding of the third Central European Conference Of Egyptologists", Acta Archaeologica I , (2009), p.125

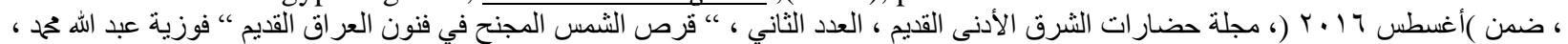

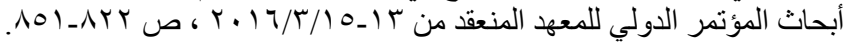

xiii P. Ameit, Muesée du Louvre, Suse, 6000 ans d'histiore, Paris ,1988, p.132;fig.83.

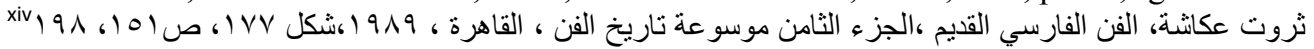

${ }^{x v}$ M.B. Garrison," Seals and the Elite at Persepolis, Some Observations on Early Achaemenid Persian Art ", Ars Orientalis 21 ( 1991),p.13; figs.21-22 .

xvi T.M. Tytus ," The Egyptian influence on the Persian winged disk, in: Proceeding of the third Central European Conference of Egyptologists", Acta Archaeologica I , (2009), p.125ff ; M.B. Garrison, op. cit., pp.19-20; fig .32 ; J. Curtis , N. Tallis , B. André-Salvini , Forgotten Empire, The World of The Ancient Persia , London , 2005, p.221; fig.398.

xvii J. Boardman ," Pyramidal Stamp Seals in the Persian Empire", Iran 8 (1970), pp.33-34, fig.12, no.114.

${ }^{x v i i i}$ H. H. Von Der Osten, "The Ancient Seals from the Near East in the Metropolitan Museum : Old and Middle Persian Seals", The Art Bulletin 13, No. 2 (1931),pp.223- 30 ; fig. c .

xix I. Mathieson, E. Bettles, S. Davies, and H. S. Smith ," A Stela of the Persian period from Saqqara ", JEA 81 (1995), pp. 23-41 .

${ }^{x x}$ P. Ameit , Muesée du Louvre, Suse , 6000 ans d'histiore ,Paris ,1988, p.132,138;fig.83

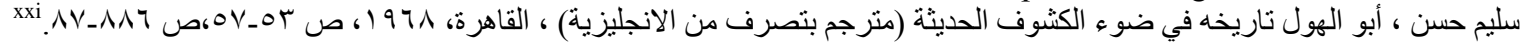

H.W.Helck "Die Liegende und gefügelte weibliche sphinx des Neun Reiches", MIO 3 , Hef1, (1955),pp.4-9 ; H.Bonnet ," Löwe" , RÄRG, Berlin (,1952),p. 427ff

22 Schweize,U. "Löwe und Sphinx im Ägypten", Äf 15, Glückstin, (1948),pp.27-65.

23 Meltzer,E.S." Horus ", Oxford Encyclopedia of Ancient Egypt II, (2001),p.119.

${ }^{\text {xxiv }}$ R. Stadelman ," Sphinx" , Oxford Encyclopedia of Ancient Egypt III, (2001),pp.307-10.

; U.Schweizer , "Löwe und Sphinx im Alten Àgypten", ẦF 15,(1948),pp.27-65.

xxv P.Amiet, Musée du Louvre, Suse 6000 ans d'histiore, Paris, 1988, p.138; fig.83.

xxvi O.W.Muscarell, "Hasanlu ", BMMA 25 (1966), p.125; fig.4 ; I.J.winter,"Pheonician and North Syrian Ivory carving in Historical context", Iraq47(1975),pl.vb ;p.15.

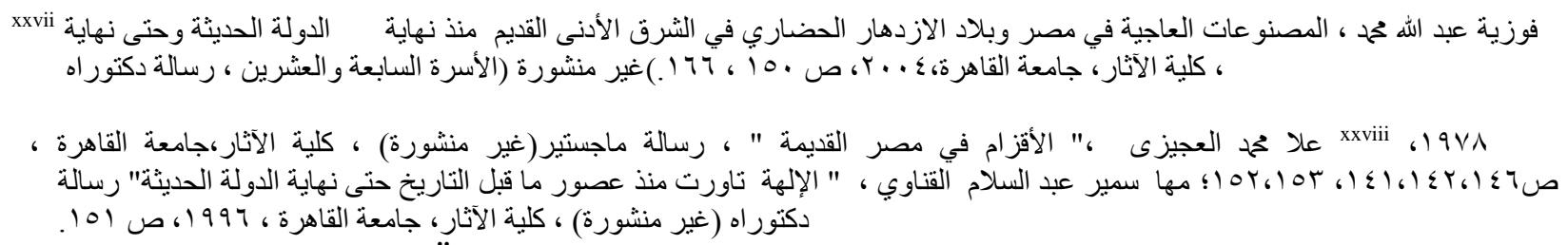

30 H.Te Velde, "Mut", LÄ VI, Weisbaden ,(1984), p.246ff. 


\section{Egyptian influence on Achaemenid Art}

xxxi P.Amiet, " Les Ivoires Achémenides de Suse" ,Syria 4,(1972),p.319; fig.28.

${ }^{x x x i i}$ L Keimer,. Die Gartenpflanzen im Alten Ägypten ,Band I , Berlin,1924,pp.10-12.

xxxiii R.Drenkhahn, "Rosette ", $\underline{L \ddot{A} V}$, Wiesbaden ,(1983),pp.309-310; M. Hirmen, Fünf Jahrtausende Mesopotamien , München , 1962, fig 84.

xxxiv P.Amiet, " Les Ivoires Achémenides de Suse" Syria 49 (1972),p. 320;fig. 30,31.

Ibid., pl.V, 2 ,a-b ; pp.181,183 35

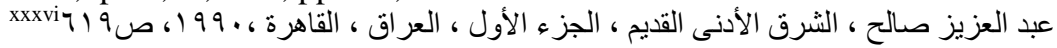

xxxvii About the Architecture motif, Egyptian "Nish", on the Ancient Near East:

E. Stern, "The Excavations at Tell Mevorah and the Late Phoenician Elements in the Architecture of Palestine", BSASOR 225( 1977),p.23ff ;H. Weippert, Palästina in Vorhellenistischer Zeit, Band I , München , 1979,p.670 ;K. Galling, "Miscellanea Archaeologica 1- Steinerne Rahmenfenster", ZDPV 83,Heft 2,(1969), pp.123-125.

xxxviii G. Contenau, Manuel d'Archéologie Orientale, III , Paris,1931, p.1335.

xxxix V.R. Herbing, "Aphrodit Parakyptusa ( Die Frau im Fenster)",OLZ 30,(1927), pp.917-922;

L . Schofield, "The Influence of Eastern Religions on the Iconography of Ivory and Bone Objects in the Kamieros Well " in : J.L.Fitton (ed.,) Ivory in Greecen and the Eastern Mediterranean from The Bronze Age to the Hellenistic Period, British Museum Occasional paper85, London ,(1992),p.176 ; pl.3 a

${ }^{x l}$ Contenau, Manuel d'Archéologie Orientale,IV, , Paris,1932, p.2226 ; F. Thureau - Dangin, Arslan Tash , Paris ,1933 pl.XXXIV,45-47,pl. XXXV ;pp.48-50 ; J.W Crowfoot, G.M .Crowfoot, "Early Ivories from Samaria ", $P E Q$ 29-30,(1931),pl.XIII,2, Id., "The Ivories From Samaria", $\underline{P E Q,(1933), p l . I I I, f i g .3,13 . ; R . S t a d e l m a n n, " S y r i s c h ~}$ - Pälästinensische Göttheiten in Ägypten", $\underline{P A ̈ 5}$, Leiden , (1967);W. Helk , "Fremde Götter in Ägypten", $\underline{L A ̈ I I}$, (1977),p. 643.

${ }^{x l i}$ M.E.L. Mallowan , Nimrud and its Remains, Vol. II, London, 1966,fig.505(ND.8005),587

42 F.Thureau-Dangin, Arslan Tash, Paris,1931, pl.xxxv,52-55,pl.xxxvi,56-60 ;p. 114

xliii P.Amiet, " Les Ivoires Achémenides de Suse" , Syria 49 (1972),p.169 ;fig.1,2.

xliv Ibid.,p.322 ;fig. 35.

${ }^{x l v}$ H.A .Hawkes, The Nimrud Ivories-Analysis of the Egyptianizing Style, (Ph.D. diss., University of London) ,1974 ,p.187,236; P. Amiet, " Les Ivoires Achémenides de Suse",Syria 49 (1972),fig.34 ;p.322. 


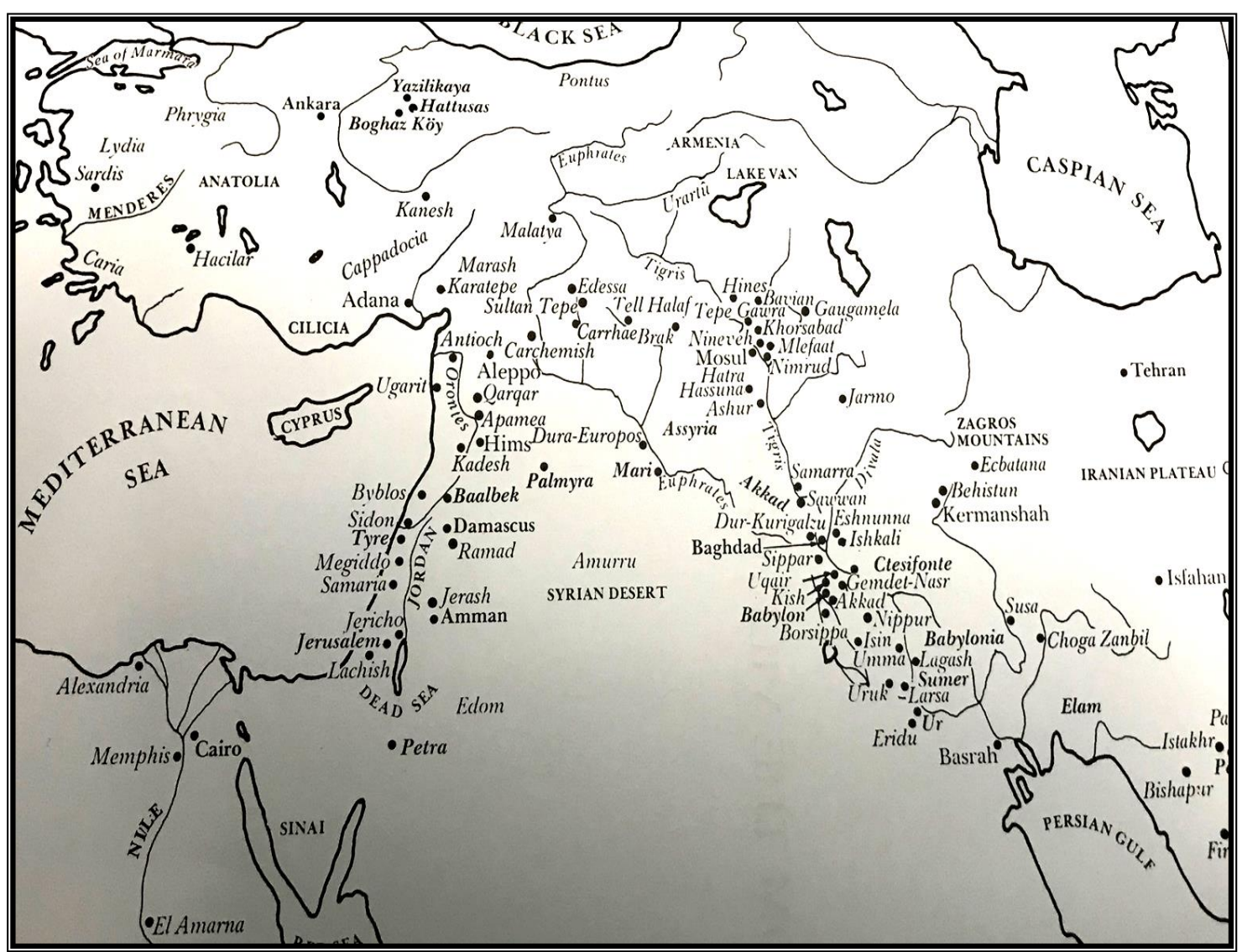

Map no.1, Ancient Near East

L. Laroche , Monuments of Civilization ,The Middle East, 1974,p.12

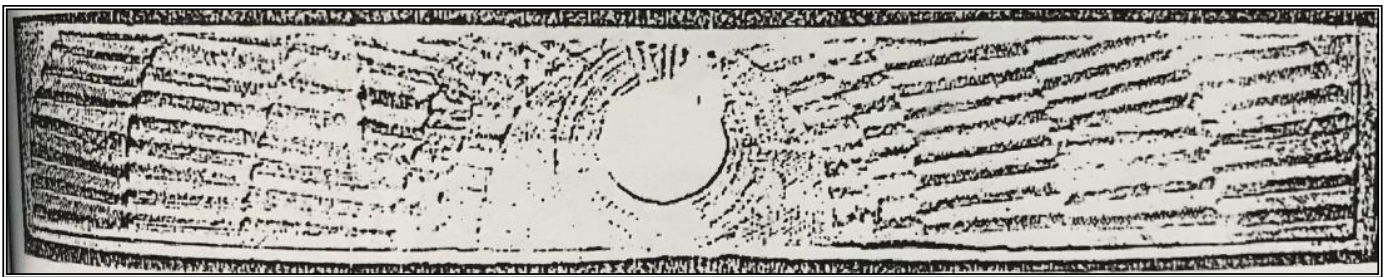

(Fig.no.1) Ivory from'North West Palace' in Nimrud, northern Iraq, dated to 865-860 B.C M.E.L. Mallowan , Nimrud and its Remains, I , London, 1966 ,p. 514; fig.418 


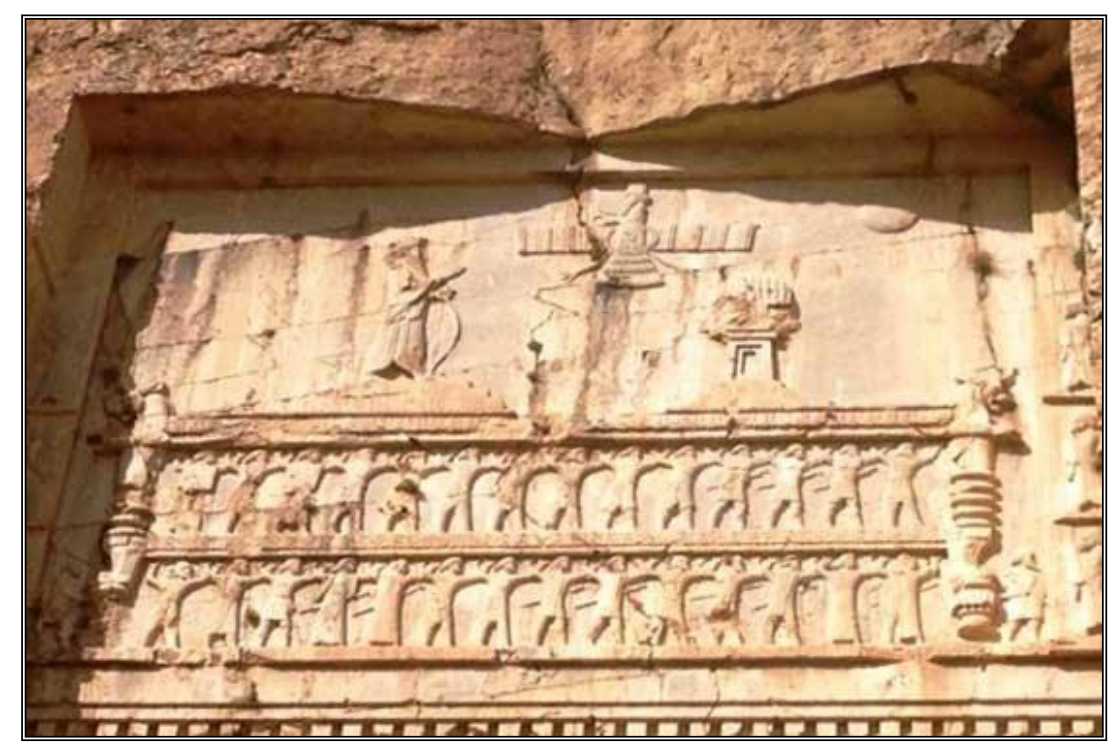

(fig.no.2) winged disk in Bisitum-rock relief with Ahura-Mazda and the king Daruis I

Tytus ,K.M. "The Egyptian Influence on the Persian winged disk", Acta Archaeologica I, $\quad$ (2009), p.125; www.jamejamonline.ir/online

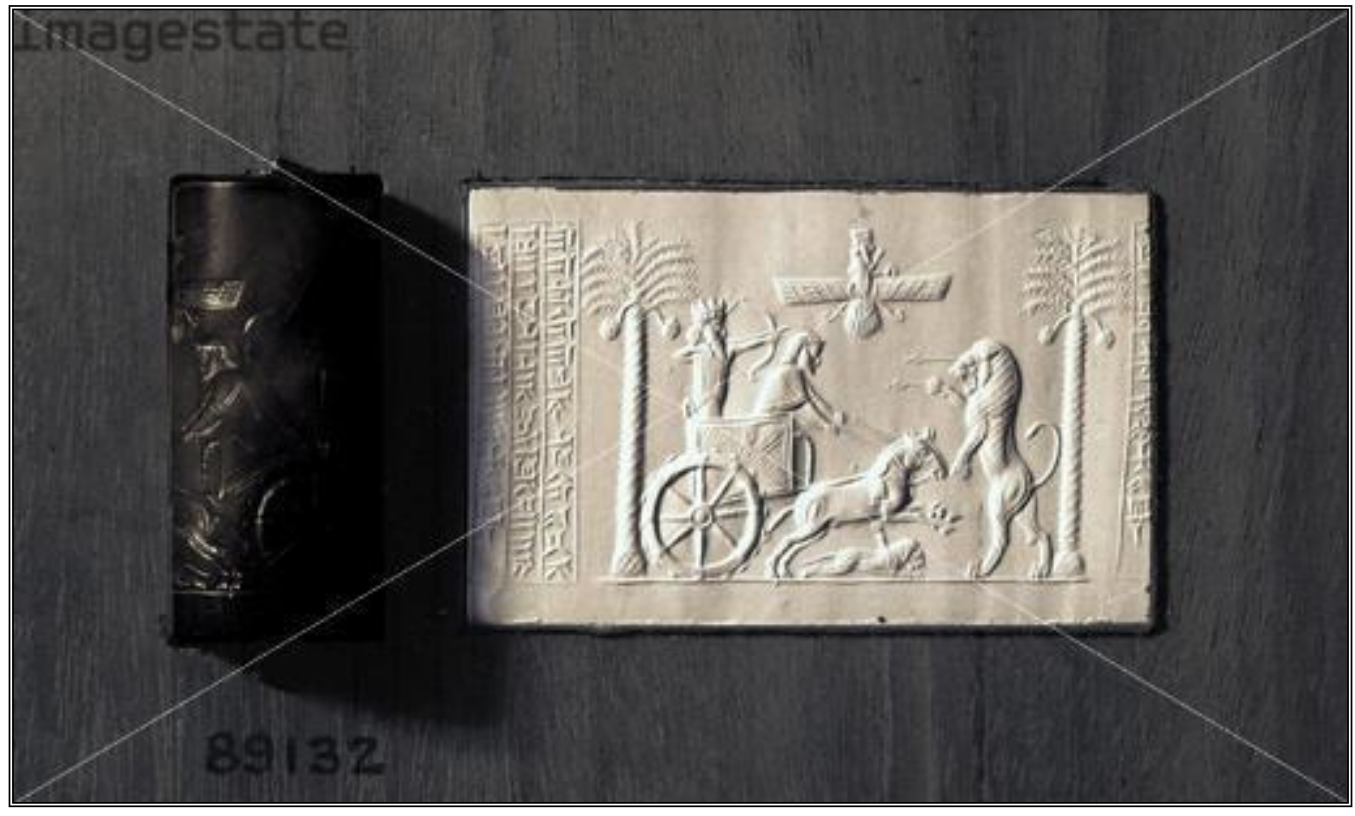

Winged disk on Darius cylinder seal, British Museum (fig.no.3)

A.B.Garrison, "Seals and the Elite at Persepolis :Some Observations on Early Achaemenid Persian Art ", Ars Orientalis 21,(1991), p.19; fig.32 


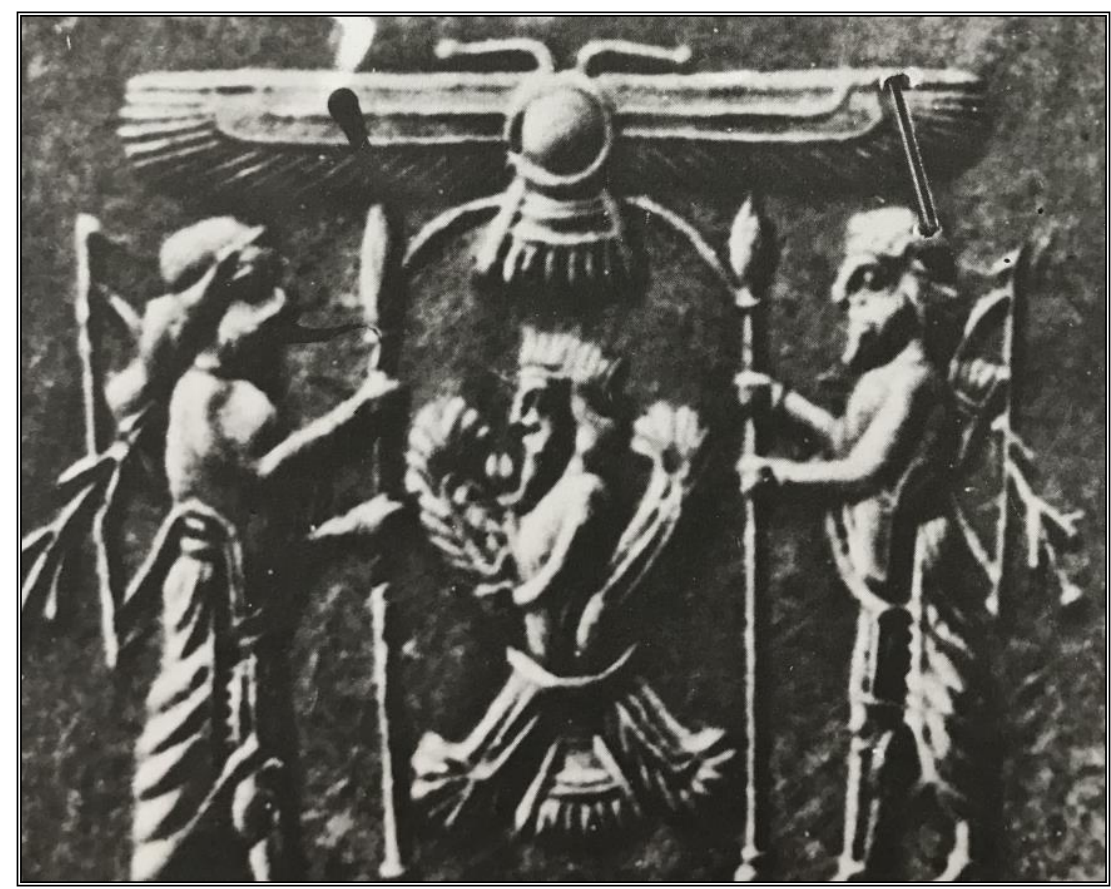

Fig.no.4) Cylinder-seal show two archer holding winged sun-disk(

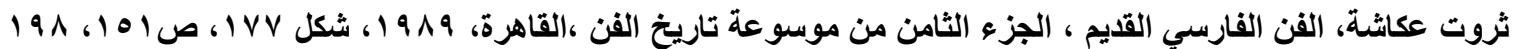

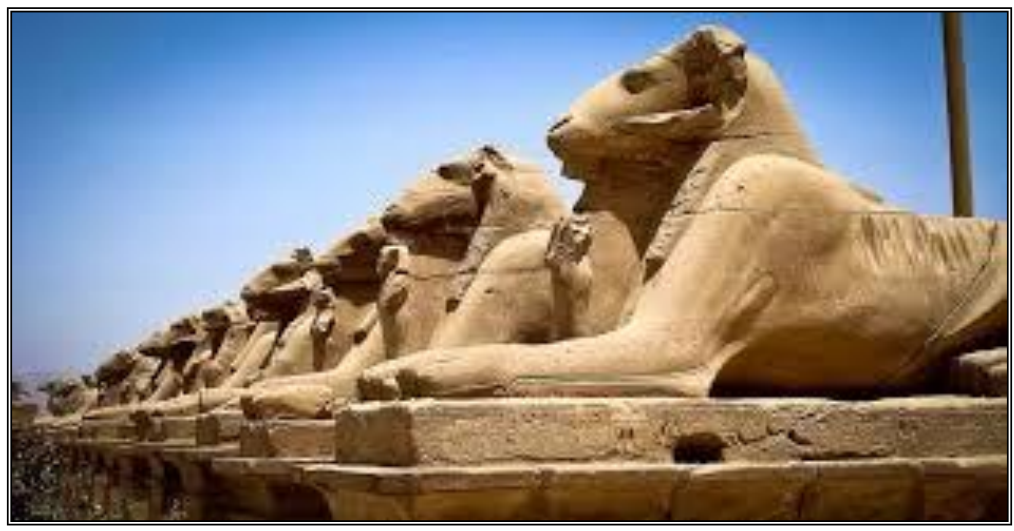

(fig.no.5) The Sphinx with head of rams -temple of Karnak https://www.google.com/url?sa 


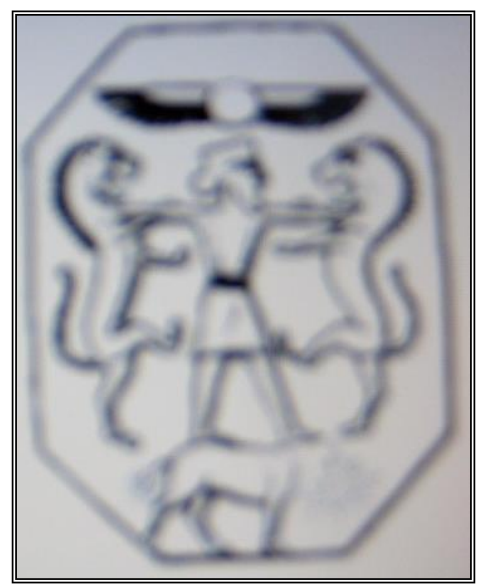

(fig.no.6) Persian hero quarrel two lions on stamp seal

J.Boardmann , Pyramidal stamp Seals in the Persian Empire , Iran , Vol.8 , (1970) , pp.33-34 ; fig. 12; no.114

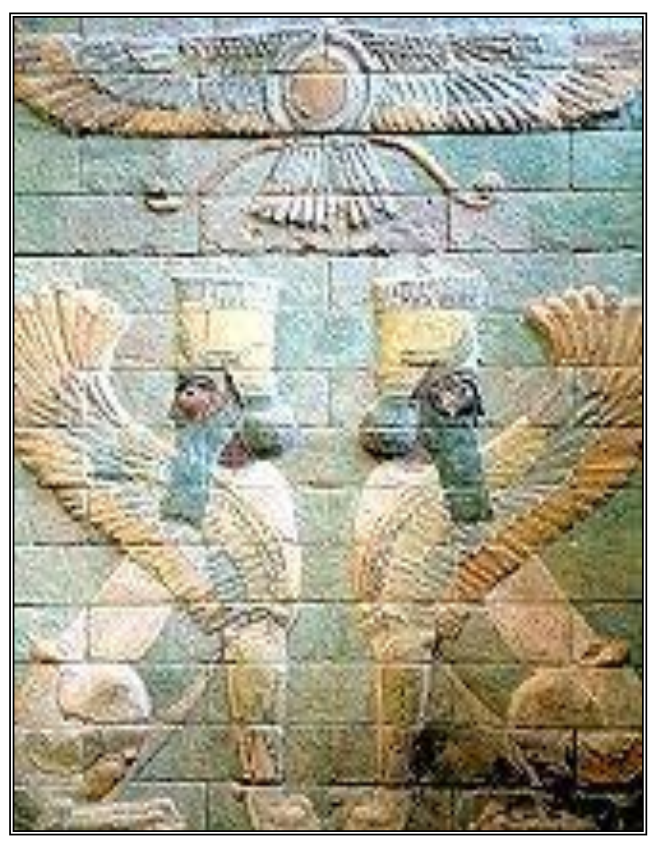

(fig.no.7) winged disk from Darius I palace with winged sphinx , Louvre Museum P.Amiet , Musée du Louvre ,Suse 6000 ans d'histiore, Paris, 1988, p.138; fig.83 


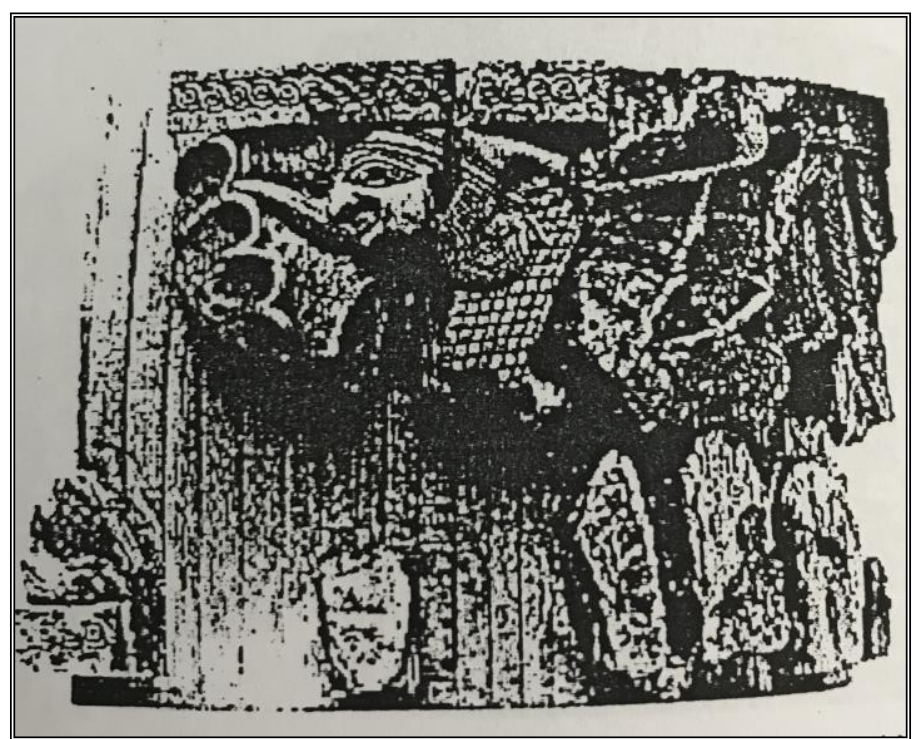

(fig.8) winged sphinx carved on piece of ivory from Hasanlu

O.W. Muscarell, Hasanlu , BMMA25,(1964), fig.6 ; p.125

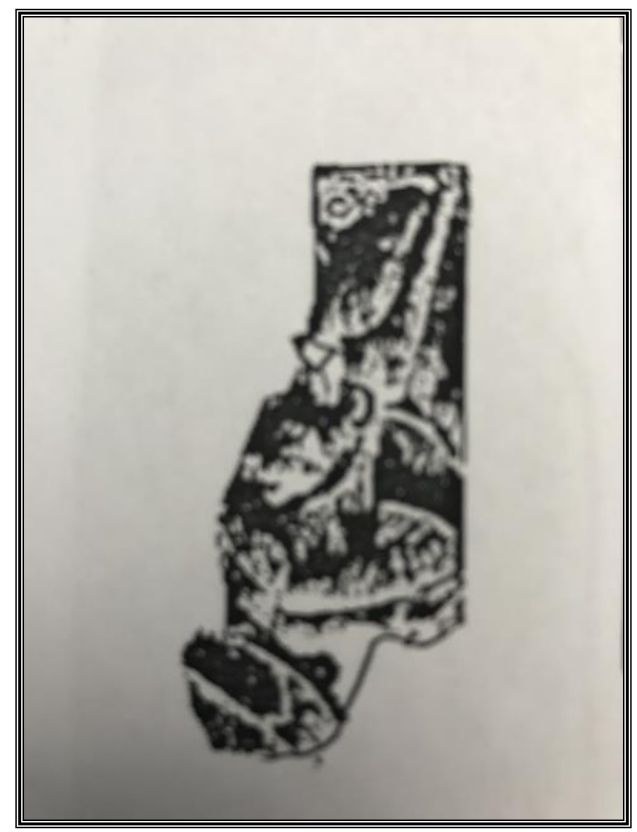

(fig.no.9) The goddess Mut in relief of Ivory from susa-dated to fifth century B.C. P.Amiet ," Les Ivoires Achémenides de Suse" Syria 49,(1972),fig.28 ;p.319 


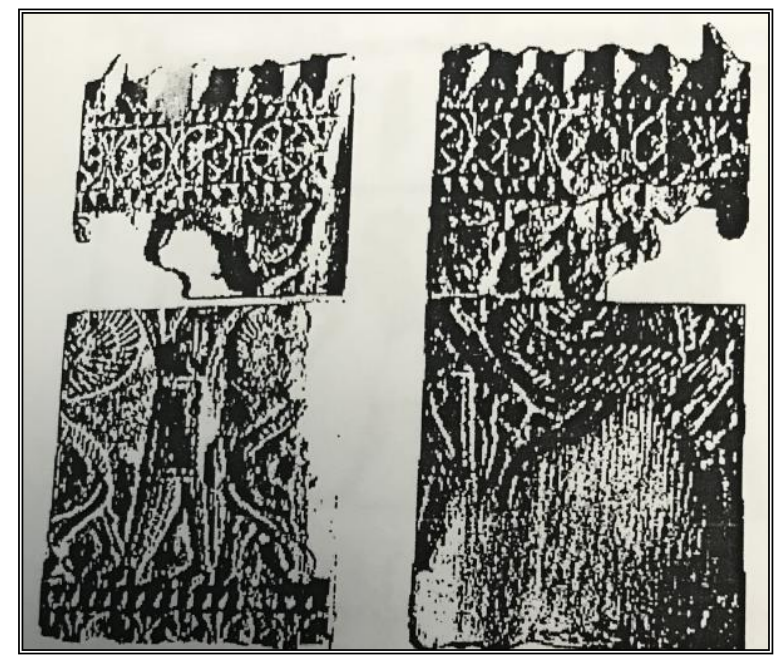

(Fig.no.10) Ivory comb from susa -Louvre museum

P.Amiet", Les Ivoires Achémenides de Suse" , Syria 49,(1972), pl.v,2 ,a-b ,p.185

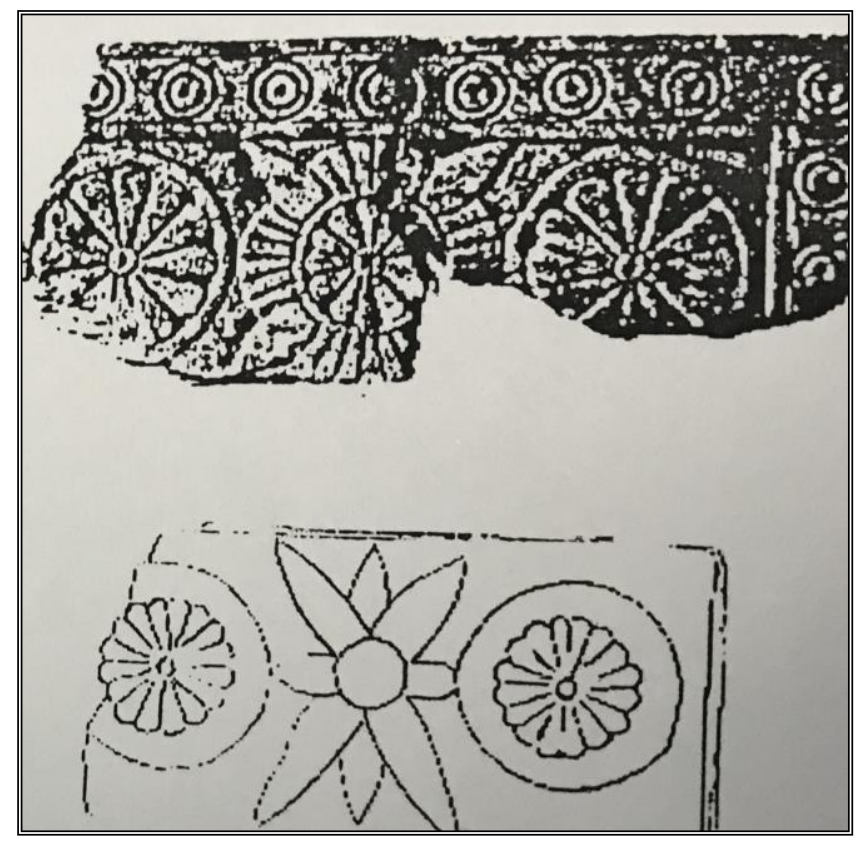

(Fig.no.11) pieces of ivory palette from suse-Louvre museum

P.Amiet ", Les Ivoires Achémenides de Suse", Syria 49,(1972), fig.6-7;p.173 


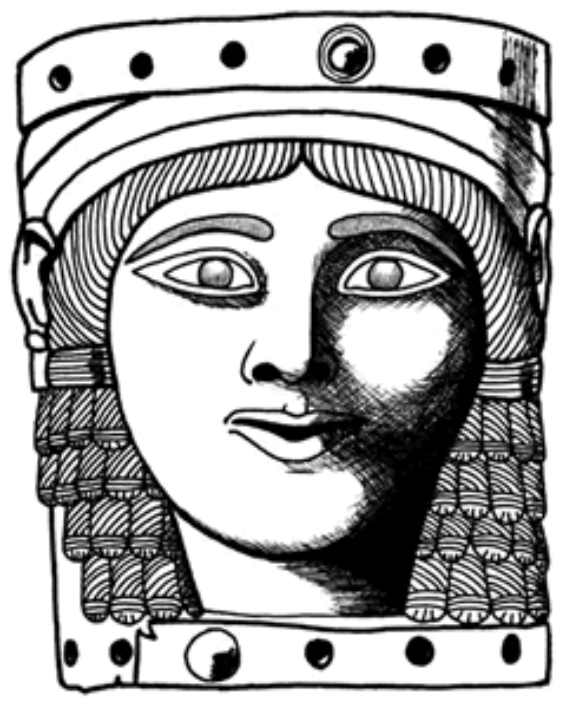

(fig.12)The "Mona Lisa" of Nimrud -Ivory

M. E.L. Mallowan , Nimrud and its Remains ,Vol. II, London,1966 ,p.587;fig.505

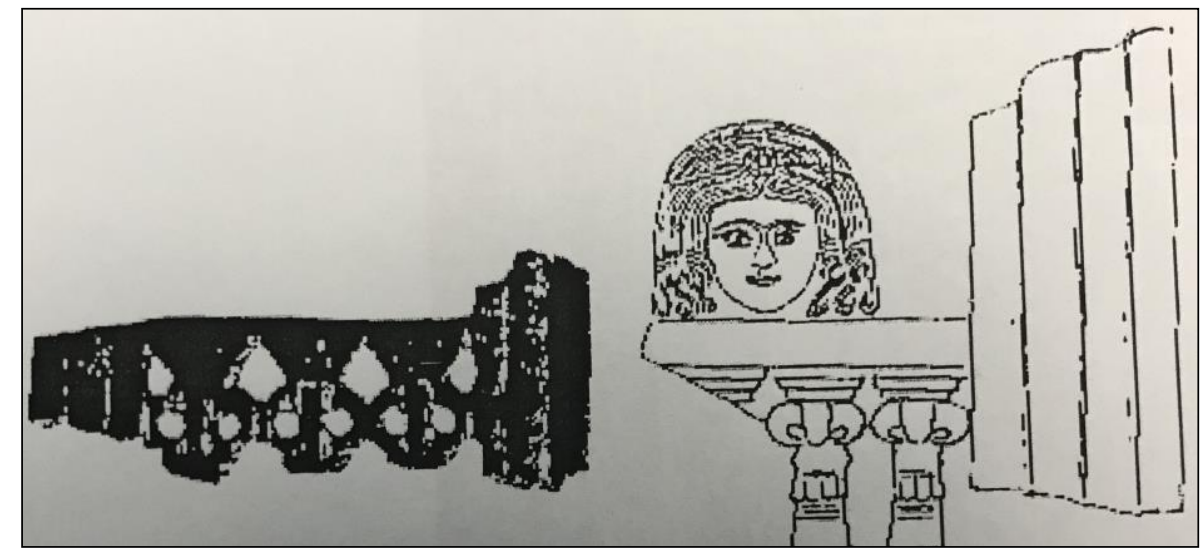

(fig.13) Lady of the window from susa-Ivory

P. Amiet , " Les Ivoires Achémenides de Suse" Syria 49,(1972), p.169;fig.1-2 




(fig.no.14) Ivory palette -cartouche of name of Daruis I -Louvre museum P. Amiet " Les Ivoires Achémenides de Suse", Syria 49,(1972),fig.35;p.322ff

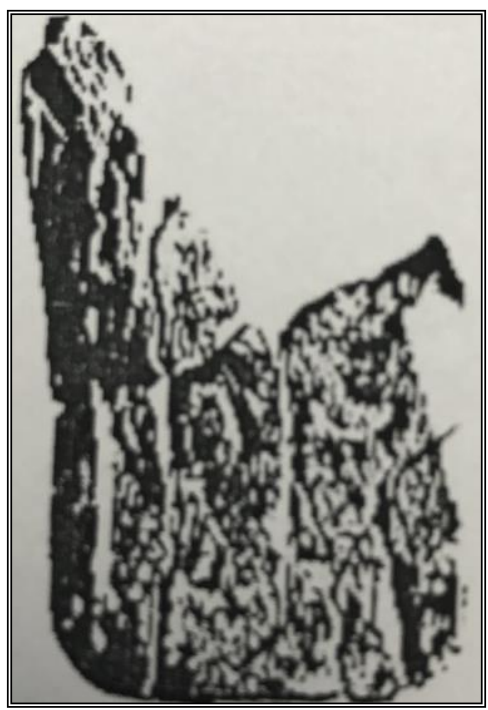

(fig.no.15) damage ivory palette represented man and hieroglyphic signs P. Amiet " Les Ivoires Achémenides de Suse", Syria 49,(1972),fig.34; p.322ff 